\title{
Best Practices in Distance Education: A Review
}

\author{
Gabriel Kofi Boahen Nsiah \\ Faculty of Arts and Social Sciences, Valley View University, Accra, Ghana \\ Email: gabrielnsiah@gmail.com
}

Received November $4^{\text {th }}, 2013$; revised December $4^{\text {th }}, 2013$; accepted December $11^{\text {th }}, 2013$

\begin{abstract}
Copyright (C) 2013 Gabriel Kofi Boahen Nsiah. This is an open access article distributed under the Creative Commons Attribution License, which permits unrestricted use, distribution, and reproduction in any medium, provided the original work is properly cited. In accordance of the Creative Commons Attribution License all Copyrights (C) 2013 are reserved for SCIRP and the owner of the intellectual property Gabriel Kofi Boahen Nsiah. All Copyright (C) 2013 are guarded by law and by SCIRP as a guardian.
\end{abstract}

\begin{abstract}
Education plays a significant role in shaping a nation, and the proliferation of Internet-based educational opportunities has expanded distance learning modalities to all parts of the globe. However, though this mode of delivery is being capitalized upon as a result of the opportunities it offers, it is still new to many nations and institutions of learning. This article therefore reviews the best practices that make distance education works. This will better inform nations and their learning institutions as they capitalize on this mode for providing access to education.
\end{abstract}

Keywords: Distance Education; Best Practices

\section{Introduction}

Technology plays a major role in the educational world (Monolescu, Schifter, \& Greenwood, 2004), and has been credited with reducing the educational gap between developed and developing nations through distance education (Breen, 2006). Learners around the world are demanding anytime and anywhere forms of education, and learning institutions are responding to that demand by implementing various forms of digitally-based education (Schrum \& Hong, 2002).

Distance education is not a new concept, but in recent years, it has assumed markedly new forms and greater prominence. Now, it is one of the fastest growing forms of education and is becoming more a part of mainstream education through courses taught by Internet or videoconferencing (Ashby, 2002). In a very short period of time academic institutions have been provided vastly expanded opportunities to provide a flexible and more open learning environment for students, and this trend continues as technology continually improves (McIsaac \& Gunawardena, 1996).

Distance education as a discipline has a sufficient research base to have an established set of practices that are considered essential elements for quality instruction. Though terminology of these best practices varies by researcher, the broad categories of best practice are relatively consistent across the literature. Strong distance education programs have specific hallmarks of good practice, and these are discussed in this article.

\section{Selecting Organization, Vision and Planning}

The importance of organization, vision and planning for distance education is emphasized by many authors (Berge \& Mrozowski, 2001; Care \& Scalan, 2001; Berge \& Clark, 2005; Stansfield et al., 2009). According to Cavalluzzo (2005), educational leaders who see the possible role for distance education in their school system should begin by assessing students' needs and identify clear objectives for the program. Berge and Clark (2005) seconded this idea by asserting that the vision of offering a virtual school program must be grounded in the reality of needs, resources, and capabilities (p. 207).

Stanfield et al. (2009) discovered that establishing a clear vision and strong leadership, as well as demonstrating a proactive approach to management that can address potential problems and explore opportunities to the full, are vital for success in distance education. In terms of developing vision and plans for implementing a distance education program, it is suggested by some authors that administrators should play that leadership role (Care \& Scanlan, 2001; Hache, 2000). Others suggest faculty leadership, explaining that without faculty leadership, the plan may be undermined (Kriger, 2001; Myers \& Ostash, 2001; Schifter, 2000). Still others promote the importance of collaborative involvement of all stakeholders - administrators, faculty, staff, and students (Hache, 2000; Hughes, 2001).

Husmann and Miller (2001) emphasized the importance of good planning based on their survey of distance education administrators. These leaders highlighted the need to provide additional support for faculty development of course materials, to make programmatic quality a high priority, and to be customer-focused by offering programs concentrated on potential client needs as essential to sound planning for any distance education program.

Poorly planned programs run the risk of not been successful. Thus, program administrators must have the vision to consider and plan for multiple aspects of their program and be consistently evaluating the program to assess effectiveness, limitations and barriers. Planning, if properly executed, provides solutions to the challenges of today (Fain, 2007; Pisel, 2008). Good planning may also depend on financial viability. In view of this, financial issues in distance education program are discussed in the following section. 


\section{Financial Issues}

Implementing a viable distance education program can require a substantial investment of human and capital resources. Though program administrators may not have to fund physical classrooms, they do have to support technologies that reliably produce the virtual classroom setting and qualified technical, instructional and support staff to run the program. Stanfield et al. (2009) stressed the importance of financial planning in distance education to assure a sustainable business model beyond the initial funding period. Cost models must be developed that accurately predict the direct and indirect costs associated with providing instruction at a distance.

Set up costs. Establishing a distance education program can be expensive, especially when starting with little equipment and big dreams (Porter, 1997). Cavalluzzo (2005) posited that educational institutions with interest in or plans of offering distance education must confront different kinds of issues surrounding the setup of the program. This includes costs and funding. Porter (1997) explained:

Before you start developing a distance learning course, you should investigate the types of technology you intend to use and determine what it will cost to start a course or program and what the projected costs will be to offer the course $\mathrm{X}$ number of times over $\mathrm{X}$ time frame. Knowing what it will cost to offer the ideal program, then determining how the-ideal can be translated into-practice and effective or locating additional sources of funding, are crucial to the success of a distance learning program ( $\mathrm{p}$. 41).

Cavalluzzo (2005) placed emphasis on the use of a student needs assessment as the basis for program objectives prior to initiating any distance education program. Once these objectives are defined, the next significant issue should be the factors that affect the costs and effectiveness of the program, followed by the need to identify funding sources and methods that can be used to launch and maintain the program.

Porter (1997) believed that distance education can be offered with lower-cost technologies but suggested careful budget planning so that quality is never compromised. Ojo, Ogidan and Olakulehin (2006) like Porter, also believed that technology plays an important role in determining the overall cost in running a distance education program. In their research, they found that distance education is cost effective as a result of its flexibility, which allows students to pace their study and finish classes at a convenient time. In other words, a student can skip a course if facing financial difficulty and return to continue the program when necessary. The challenge this poses for those implementing the program is that a steady tuition stream may or may not be present, as students periodically drop out of the program based on personal circumstances or finance. Thus, it is incumbent on the distance education planner to identify financial strategies such as commercial secretarial services and stores/bookshops that maximize efficiency and contain costs.

\section{Cost Effectiveness and Efficiency}

Butcher (2000) distinguished between cost effectiveness and cost efficiency. He defined cost efficiency as having to do with "cheapness" of educational provision-usually expressed in terms of per-student costs - while cost effectiveness has to do with striking the optimal balance between cost, student numbers, and educational quality, a balance which according to Butcher, will be entirely different for different educational contexts.

Butcher (2000) believed the concept of cost-effectiveness represents the balancing act that constitutes distance education. According to this author, there is no magical formula that leads to cost-effective education; rather, cost-effectiveness needs to be measured on an ongoing basis in relation to changing contextual requirements. Bartley and Golek (2004) posited-To comprehensively evaluate the cost effectiveness of online learning, practitioners and adopters need a comprehensive tool to evaluate the costs associated with online learning as compared to those associated with face-to-face learning (p. 173).

To accomplish this program, administrators must carefully consider costs and budget appropriately. Determining start up costs, ongoing expenses, and the inevitable price of constant upgrades inherent to information technology is vital to establishing and sustaining an effective program.

\section{Classroom Facilitators}

Online facilitation, in broad terms can be described as the act of managing the learners and the learning through an online medium (Australian Flexible Learning Framework, 2002). The importance of qualified and engaged classroom facilitators is recognized in distance education programs by researchers (Mac-Gregor \& Atkinson, 2002-2003; Spencer, 2002; Wang, 2008).

Literature has revealed four interrelated roles played by facilitators in distance education - intellectual, social, managerial, and technical (Hoostsein, 2002; Wang, 2008). Intellectually, facilitators help students achieve learning objectives by helping them comprehend critical learning concepts. They also distribute and collect class materials, proctor exams and quizzes, and report class needs or problems as they occur (Spencer, 2002; Wang, 2008). Socially, the facilitator creates and maintains a friendly environment. Such an environment makes students feel safe and comfortable interacting with the instructor and with each other (Anderson, 2004; Wang, 2008).

Managerially, the facilitator sets agendas such as timeline, rules, and norms for smooth online discussions. In so doing, the facilitator demonstrates leadership abilities by keeping the students focused. Technically, the facilitator assists teachers and students by operating electronic classroom media that are appropriate to the delivery of each class session. In addition to that, the facilitator also helps students get familiar and comfortable with the delivery technology (Spencer, 2002; Wang, 2008). According to Spencer (2002), facilitators act as theeyes and ears of the instructor who is not physically present in the remote classroom by giving directions, making announcements, answering questions, and consulting with full-time staff. Both the instructor and students rely on the facilitator to bridge the physical distance that separates them by minimizing technological and administrative obstacles.

In their research, Yi and Majima (1993) found that the relationship between the facilitator and the students impacted the way the students learned. Positive relationships between the facilitator and the students affect the students' learning positively, while negative relationships affect the students negatively. According to MacGregor and Atkinson (2002-2003), facilitators should be mentors/role models to the students. 


\section{Tapping Student Motivation}

Educators in general believe that all students can learn. But the strength, desire, and temperament to learn vary from one student to the other (Sankaran \& Bui, 2001). Sankaran and Bui further stated,

Students who choose distance education need a high level of motivation if they are to complete the course work successfully. During their studies, they often have to work by themselves with little or no opportunities for face-toface or peer interaction. They will have to deal with more abstract and ambiguous situations than someone taking a lecture class. They need to be efficient in time management, be responsible and in control of their studies and maintain an image of self-worth and self-efficacy. They should see the value of the education and be able to postpone current enjoyments and cope with interruption life frequently entails (p. 2).

Ormrod (2006), who also spoke to the importance of tapping student motivation for learning and motivation for pursuing that learning at a distance, offered the following guidelines for good practice in fostering student motivation:

- When students approach a learning task believing they can make sense of the information - that is, when they have a meaningful learning set-they are more likely to learn that information meaningfully,

- Students with a high sense of self-efficacy are more likely to exert effort when attempting a new task. They are also more likely to persist (to try, try again) when they confront obstacles to their success. In contrast, students with low-self efficacy about a task will put in little effort and give up quickly in the face of difficulty,

- People often set goals for themselves and direct their behavior accordingly; in essence, they are motivated to accomplish their goals,

- Students with high achievement motivation seek out challenging tasks that they know they can accomplish with effort and persistence. They really do not rest on their laurels; instead, they set increasingly high standards for excellence as their current standards are met (Ormrod, 2006: p. 200368).

Research has shown that students exhibit greater motivation when the course content is of interest to them and they perceive some personal relevance in the content (Adler, et al., 2001; Brass, 2002; Burke \& Moore, 2003). In their research on the impact of motivation on performance, Sankaran and Bui (2001) found motivation and performance to be significantly correlated and that high motivation is associated with high performance, while low motivation is correlated with low performance. In similar research, Dunigan and Curry (2006) found high motivation to be associated with high performance and less motivation to be associated with low performance.

According to Parker (1999), distance education necessitates the use of real world problems that students work on in teams to find solutions for and consistent levels of interaction among class members and with the instructor. In view of the above, Parker suggested that distance education courses should therefore be designed in a manner that would make room for interaction through questioning, evaluation, and analysis. Such activities support student motivation by linking theory to practice.

Conaway, Easton and Schmidt (2008) posited that online in- structors should recognize their roles as facilitators who monitor discussion and provide feedback to sustain student motivation and promote performance. To encourage discussion, they suggested that the instructor should lead the discussion, summarize the discussion points, and provide feedback. The instructor then may have students assume roles for various assignments which automatically place them in interactive roles. And once interaction is initiated, the instructor may disengage as the students take over.

Russo and Campbell (2004) also noted that the way instructors respond to students' e-mails and other forms of communication have great impact on how well students learn online. However, Dennen et al. (2007) offered that communication through e-mail and assignment feedback is not enough to satisfy learners. This research suggested that learners are used to having an instructor in the face-to-face classroom and wish to see that same sort of presence in the virtual classroom (p. 9).

Dennen et al. (2007: p. 9) also emphasized the importance of clearly presenting the expectations of the course to learners. They said instructors should not assume that their expectations are as clear to the students as it is [sic] to them. They believed that students often feel more secure when they have the expectation explicitly stated or confirmed. Moore and Kearsley (2005), concurred with the above assertion as evidenced by the following quote:

Only when a course has clear learning objectives - unambiguous statements of what the student should be able to do as evidence of having learned - can instructional designers identify the most suitable learning experiences, make good technology and media selections, and design appropriate evaluation instruments (p. 125).

Dennen et al. (2007) suggested the provision of examples of completed assignments or models of expected discussion behavior as a way of doing this. They believed that this provision could be readily built into the course design so students do not have to ask for them.

\section{Instructors as Co-Learners}

Evans et al. (2007) noted that the distance education environment affords benefit to both instructors and students by changing the dynamic of the teacher-student relationship. Following a constructivist philosophy, Evans et al. (2007) recommended that a sound approach to distance education involves instructional strategies that empower the learners to construct their own meanings from the content and apply it in personal ways. Sound instruction, then, relies upon the ongoing initiative of engaged instructors who are committed to teaching within the online environment, and to approaching their instruction as co-learners with their students. Program administrators must set appropriate standards for hiring and retention of distance education faculty, and ongoing development opportunities should be provided. Meeting instructors' professional development needs enhances students learning (Levy, 2003; Lockard, 2001).

\section{Sound Instructional Design and Technical Support Resources}

Because distance education involves the physical separation of teacher and student, the design of instruction must be highly precise to make sure that students have all of the information 
they need and that it is presented in a logical and easy-to-follow format. Instructional design principles that operate from established instructional theory should be standardized and applied to course environments so that students have a consistent interface with which to engage and a logical flow to the course materials. Course design should focus on the simplest way to convey the content and should be transparent to the learners (DiPietro et al., 2008; Evans et al., 2007; Levy, 2003).

\section{Adequate Support, Funding, and Compensation}

Administrators must ensure the availability of adequate support from the school, including appropriate technology with high quality sound and video, as well as support for distributing homework and for arranging proctored exams. In addition, funding mechanisms must also consider appropriate compensation for the design and delivery of distance education courses. Because distance education requires more of instructors' time for preparation and interacting with students, schools should compensate instructors and teaching assistants appropriately for extra time spent. Such considerations should be integrated into program planning and budgeting, and program administrators should periodically audit their rates to assure that they are competitive with other programs (DiPietro, et al., 2008; Evans et al., 2007; Levy, 2003).

\section{Established Policies for Intellectual Property and Fair Use}

Another best practice for distance education programs stipulates that policies should be in place that explicitly outline the rights of ownership and future use of all instructional materials and media. Course development should be contracted according to specified terms of ownership and fair use, and rules should be employed consistently to avoid any misunderstanding between course developers and the program. Therefore, establishing right of ownership and future use policy is necessary to avert problems before they occur (Evans et al., 2007; Gasaway, 2002; Levy, 2003).

\section{Conclusion}

Distance education is still new in most countries, especially in the developing world. It is a good mode for delivering education. There are a lot of benefits that go with distance education such as flexibility and provision of education to the remotest areas, cost effectiveness, etc. Therefore, serious nations and institutions interested in real development cannot do away with distance education. It will provide the opportunity for all, especially workers and parents to access education even with their busy schedules.

The implementation of an effective distance education program, like any other program, can be facilitated by following established standards of practice and reliance upon the body of literature related to the discipline. The lack of knowledge makes people perish and knowledge is power. Therefore being well informed in distance education will ensure successful establishment. This article therefore outlined some of the best practices for successful implementation and administration of an effective distance education program. Modern academic institutions must seize the opportunities that distance education offers to advance their nations.

\section{REFERENCES}

Adler, R. W., Milne, M. J., \& Stablein, R. (2001). Situated motivation: An empirical test in an accounting class. Canadian Journal of Administrative Sciences, 18, 101-116. http://dx.doi.org/10.1111/j.1936-4490.2001.tb00248.x

Anderson, T. (2004). Teaching in an online learning context. In T. Anderson, \& F. Elloumi (Eds.), Theory and practice of online learning (pp. 273-294). Athabasca: Athabasca University.

Ashby, C. M. (2002). Distance education: Growth in distance education programs and implications for federal education policy. http://www.gao.gov/new.items/d021125t.pdf

Australian Flexible Learning Framework (2002). Effective online facilitation: Australian flexible learning quick guide series. $\mathrm{http}: / /$ pre2005.flexiblelearning.net.au/guides/facilitation.pdf

Bartley, S. J., \& Golek, J. H. (2004). Evaluating the cost effectiveness of online and face-to-face instruction. Educational Journal and Technology, 7, 167-175.

Berge, Z. L., \& Clark, T. (2005). Virtual schools: Planning for success. Columbia University, NY: Teachers College Press.

Berge, Z. L., \& Mrozowski, S. (2001). Review of research in distance education, 1990 to 1999. The American Journal of Distance Education, 15, 5-19. http://dx.doi.org/10.1080/08923640109527090

Brass, K. (2002). Pushing E-learning. Sales and Marketing Management, 154, 56.

Breen, P. (2006). Coming out of the darkness of the past. Turkish Online Journal of Distance Education, 7, 1-8.

Burke, L. A., \& Moore, J. E. (2003). A perennial dilemma in OB education: Engaging the traditional student. Academy of Management Learning \& Education, 2, 37-53. http://dx.doi.org/10.5465/AMLE.2003.9324016

Butcher, N. (2000). Distance education in developing countries (knowledgebank paper 3). http://imfundo.digitalbrain.com/imfundo/web/teach/kb3/?verb=vie

Care, W. D., \& Scanlan, J. M. (2001). Planning and managing the development of courses for distance delivery: Results from a qualitative study. The Online Journal of Distance Learning Administration, 4. http://www.westga.edu/ distance/ojdla/summer42/care42.html

Cavalluzzo, L. (2005). Cost, funding, and the provision of online education. In Z. L. Berge, \& T. Clarke (Eds.). Virtual schools: Planning for success. New York, NY: Teachers College Press.

Conaway, R. N., Easton, S. S., \& Schmidt, W. V. (2008). Strategies for enhancing student interaction and immediacy in online courses. Business Communication, 68, 23-35. http://dx.doi.org/10.1177/1080569904273300

Dennen, V. P., Darabi, A. A., \& Smith, L. J. (2007). Intructor-learner interaction in online courses: The relative perceived importance of particular instructor actions on performance and satisfaction. Distance Education, 28, 65-79. http://dx.doi.org/10.1080/01587910701305319

DiPietro, M., Ferdig, R. E., Black, E. R., \& Preston, M. (2008). Best practices in teaching K-12 online: Lessons learned from Michigan virtual school teachers. Journal of Interactive Online Learning, 7, 16-19.

Dunigan, B., \& Curry, K. J. (2006). Motivation and learning strategies of students in distance education. Journal of the Mississippi Academy of Sciences.

http://www.thefreelibrary.com/Motivation+and+learning+strategies+ of +students+in+distance+education.-a0148313528

Evans, S. R., Wang, R., Yeh, T., Anderson, J., Haija, R., McbratneyOwen, P. M., Peeples, L., Sinha, S., Xanthakis, V., Rajicic, N., \& Zhang, J. (2007). Evaluation of district learning in an introduction to biostatistics class: A case study. Statistics Education Research Journal, 6, 59-77.

Fain, P. (2007). Vision for excellence. The Chronicle of Higher Education, 54, A26-A29.

Gasaway, L. N. (2002). Drafting a faculty copyright ownership policy. The Technology Source, 2.

http://ts.mivu.org/default.asp?show=article\&id $=982$

Hache, D. (2000). Strategic planning of distance education in the age of teleinformatics. The Online Journal of Distance Learning Admini- 
stration, 1.

http://www.westga.edu/ distance/Hache12.html

Hoostein, E. (2002). Wearing four pairs of shoes: The roles of e-learning facilitators.

http://www.learningcircuits.org/2002/oct2002/elearn.html

Hughes, T. P. (2001). Through a glass darkly: Anticipating the future of technology-enabled education. Educause Review, 36. http://www.educause.edu/ir/library/pdf/erm0140.pdf

Husmann, D. E., \& Miller, M. T. (2001). Improving distance education: Perceptions of program administrators. The Online Journal of Distance Learning Administration, 4.

http://www.westga.edu/ distance/ojdla/spring41/husmann41.html

Kriger, T. J. (2001). A virtual revolution: Trends in the expansion of distance education. Education at a Distance, 15.

http://www.usdla.org/ED_magazine/illuminactive/NOV01_Issue/arti cle02.html

Levy, S. (2003). Six factors to consider when planning online distance learning programs in higher education. Online Journal of Distance Learning Administration, 6.

Lockard, L. A. (2001). Collaborative technology planning. Technical Horizons in Education.

http://www.thejournal.com/magazine/vault/articleprintversion.cfm?ai $\mathrm{d}=3660$

MacGregor, S. K., \& Atkinson, T. R. (2002-2003). Facilitating learning interactions in the two way video classroom. Journal of Educational Technology Systems, 31, 45-62. http://dx.doi.org/10.2190/KH51-CDC6-ADBL-J969

McIsaac, M. S., \& Gunawardena, C. N. (1996). Handbook of research for educational communications and technology: A project of the association for educational communications and technology. New York, NY: Simon \& Schuster Macmillan.

Monolescu, D., Schifter, C. C., \& Greenwood, L. (2004). The distance education evolution: Issues and case studies. Hershey, PA: Information Science.

Moore, M. G., \& Kearsley, G. (2005). Distance education: A systems view. Belmont, CA: Thomson Wadsworth.

Myers, P., \& Ostash, H. (2001). Building a virtual campus. Journal of the Faculty Association of California Community Colleges, 7.

Ojo, O. D., Ogidan, R., \& Olakulehin, F. K. (2006). Cost effectiveness of open and distance learning in Nigeria: Responses from focus group discussion. Online Journal of Distance Learning Administration, 9.
Ormrod, J. E. (2006). Educational psychology: Developing learners. Upper Saddle River, NJ: Pearson Merrill Prentice Hall.

Parker, A. (1999). Interaction in disatance edcuation: The critical conversation. Educational Technology Review, 13-17.

Pisel, K. P. (2008). A strategic planning process model for distance education. Online Journal of Distance Learning Administration, XI. http://www.westga.edu/ distance/ojdla/summer112/pisel112.html

Porter, L. R. (1997). Creating the virtual classroom: Distance learning with the Internet. New York, NY: Wiley Computer Publishing.

Russo, T. V., \& Campbell, S. W. (2004). Perceptions of mediated presence in an asynchronous online course: Interplay of communication behaviors and medium. Distance Education, 25, 215-232.

http://dx.doi.org/10.1080/0158791042000262139

Sankaran, S. R., \& Bui, T. (2001). Impact of learning strategies and motivation on performance: A study in web-based instruction. Journal of Instructional Psychology.

http://findarticles.com/p/articles/mi_m0FCG/is_3_28/ai_79370574/

Schifter, C. C. (2000). Faculty motivators and inhibitors for participation in distance education. Educational Technology, 40, 43-46.

Schrum, L., \& Hong, S. (2002). From the field: Characteristics of successful tertiary online students and strategies of experienced online educators. Education and Information Technology, 7, 5-11. http://dx.doi.org/10.1023/A:1015354423055

Spencer, J. (2002). USU distance education site facilitator handbook. Logan: Utah State University.

http://www.usu.edu/uenss/Handbook-Sep02.pdf

Stansfield, M., Connolly, T., Cartelli, A., Jimoyiannis, A., Magalhães, H., \& Maillet, K. (2009). The identification of key issues in the development of sustainable e-learning and virtual campus initiatives. Electronic Journal of e-Learning, 7, 155-164.

Wang, Q. (2008). Student-facilitator's roles in moderating online discussion. British Journal of Educational Technology, 39, 2008. http://dx.doi.org/10.1111/j.1467-8535.2007.00781.x

Willis, B. (2000). Instructional development for distance education. Strategies for Learning at a Distance. http://www.uidaho.edu/evo/dist2003.html

Yi, H., \& Majima, J. (1993). The teacher-learner relationship and classroom interaction in distance learning: A case study of the Japanese language classes at an American high school. Foreign Language Annals, 26, 21-30.

http://dx.doi.org/10.1111/j.1944-9720.1993.tb01147.x 